\title{
Öğretmenlik Uygulaması Dersi Kapsamında Karşılaşılan Sorunlar ve Çözüm Önerileri ${ }^{1}$
}

\author{
Züleyha YILDIRIM YAKAR
}

Dr. Öğr. Üyesi, Kahramanmaraş Sütçü İmam Üniversitesi, Eğitim Fakültesi, Matematik ve Fen Bilimleri Eğitimi Bölümü zuleyhayildirim@ksu.edu.tr

Orcid ID: https://orcid.org/0000-0002-6420-2205

\section{Emine UZUN}

Dr. Öğr. Üyesi, Kahramanmaraş Sütçü İmam Üniversitesi, Eğitim Fakültesi, Matematik ve Fen Bilimleri Eğitimi Bölümü euzun@ksu.edu.tr

Orcid ID: https://orcid.org/0000-0002-9497-1558

\section{Betül TEKEREK}

Dr. Öğr. Üyesi, Kahramanmaraş Sütçü İmam Üniversitesi, Eğitim Fakültesi, Matematik ve Fen Bilimleri Eğitimi Bölümü btekerek@ksu.edu.tr

Orcid ID: https://orcid.org/0000-0001-7066-6885

\section{$\ddot{O} \mathbf{z}$}

Araştırmanın amacı öğretmenlik uygulaması dersi sürecinde öğretmen adayları, uygulama öğretim elemanı, uygulama öğretmeni, uygulama okulu koordinatörü ve uygulama okulu müdürünün birbirleri ile ilgili yaşadıkları sorunları ve çözüm önerilerini belirlemektir. Araştırmanın katılımcılarını 20172018 Eğitim-Öğretim yılında bir devlet üniversitesinde Sınıf Öğretmenliği ve Fen Bilgisi Öğretmenliği Lisans Programının son sınıfında öğrenim gören toplam 19 öğretmen adayı ve öğretmenlik uygulaması dersi kapsamında görevlendirilen 8 uygulama öğretmeni, 4 uygulama öğretim elemanı, 4 uygulama okulu koordinatörü ve 4 uygulama okulu müdürü oluşturmaktadır. Bu araştırma nitel araştırma modeli olan bir durum çalışması olup verilerin toplanmasında yarı yapılandırılmış görüşme formu kullanılmıştır. Elde edilen verilerin analizinde içerik analizi yöntemi kullanılmıştır. Araştırmanın sonucunda öğretmenlik uygulaması dersi kapsamında ilgili tarafların birbirlerine karşı birçok noktada

\footnotetext{
${ }^{1}$ Makale Geliş/Kabul Tarihi: 05.12.2019/ 15.03.2021

Künye Bilgisi: Yıldırım Yakar, Z., Uzun, E. ve Tekerek, B. (2021). Öğretmenlik uygulaması dersi kapsamında karşılaşılan sorunlar ve çözüm önerileri. Kahramanmaraş Sütçü İmam Üniversitesi Sosyal Bilimler Dergisi, 18(1), 220-245. DOI: 10.33437/ksusbd.655590
} 


\title{
Z.Yıldırım Yakar-E.Uzun-B.Tekerek Öğretmenlik Uygulaması Dersi...
}

görev ve sorumluluklarını tam olarak yerine getiremedikleri anlaşılmıştır. Araştırmada ayrıca yaşanan sorunlara yönelik katılımcıların çözüm önerilerine de yer verilmişstir.

Anahtar Kelimeler: Öğretmenlik Uygulaması, Paydaşlar, Sorunlar, Çözüm Önerileri.

\section{Problems Encountered Within the Scope of Teaching Practice Course and Solution Suggestions}

\begin{abstract}
The aim of the study is to determine the problems experienced by practice school headmasters, practice school coordinators, practice teachers, university supervisors and teacher candidates about each other in the process of teaching practice and the solution suggestions of them. The participants of the study consisted of 19 teacher candidates studying in the last year of the Primary Education program and Science Education program in 2017-2018 academic year at a state university and 8 practice teachers, 4 university supervisors , 4 practice school coordinators and 4 practice school headmasters who are assigned within the scope of teaching practice course. This research is a case study which is a qualitative research model and semi-structured interview form was used to collect the data. Content analysis method was used in the analysis of the obtained data. According to the findings of the study, it was understood that the related parties could not fulfill their duties and responsibilities towards each other within the scope of the teaching practice course. And in this study, suggestions for overcoming these problems through the views of the partners were determined.
\end{abstract}

Keywords: Teaching Practice, Partners of Teaching Practice Course, Problems, Suggestions.

\section{GİRIŞ}

Eğitim fakültelerinde hizmet öncesi eğitim kapsamında öğretmen adaylarına verilen akademik derslerin içeriğinin ve öğretmenlik uygulamasının niteliği öğretmenlerin yetkinlik düzeylerinin artmasında önemlidir (MEB, 2017). Öğretmen adaylarının derslerine ilişkin bilginin yanı sıra, mesleki becerileri edinmeleri gerekir. Mesleki eğitim, hem teorik eğitim derslerini (öğretmenliğin eğitim teorisi, eğitim psikolojisi vb.) hem de okullarda uygulamalı olarak öğretimin gözlemlenmesini ve muhtemelen tam sorumluluk alınarak biraz zaman geçirilmesini sağlayan uygulamalı eğitim derslerini içermektedir (Eurydice, 2015: 32). Teorik dersler öğretmen eğitiminin kuramsal boyutunu oluştururken, 
öğretmenlik uygulaması alan bilgisi, genel kültür ve öğretmenlik formasyonu derslerinde kuramsal olarak edinilen bilgilerin beceriye dönüştürülmesi kısmını oluşturmaktadır (Hurioğlu, 2016: 2). Öğretmenlik uygulaması dersi sayesinde öğrenciler üniversite derslerinde edindikleri teorik bilgileri, okullardaki mentörlerinin rehberliğinde sınıf öğretimi gerçekleştirerek özümseme firsatı edinirler (Darling-Hammond, 2006: 308). Bu nedenle teorik dersler öğretmen adaylarını uygulama okullarının müfredatı ile başa çıkabilmeleri ve öğretim uygulamalarında kendilerine güvenebilmeleri için sağlam konu bilgisi ve pedagojik içerik bilgisi ile donatmalıdır (Smith ve Lev Ari, 2005:299).

Öğretimin çok karmaşık bir süreç olması nedeniyle hizmet öncesi öğretmen eğitiminde verilen teorik dersler, geniş pedagojik içerik bilgisi, içeriğe hâkimiyet, sorun çözebilme, sınıf olaylarının algılanması gibi yeni nesil öğretmenleri hazırlamak için gerekli bütün deneyimleri ve bilgi birikimini sağlayamayabilir. Öğretmenlik uygulaması dersi bu noktada oluşabilecek eksiklikleri gidermede öğretmen yetiştiren programların temel taşıdır. Bu nedenle öğretmen adaylarının gelecekte üstlenecekleri öğretmenlik rolüne hazırlanmaları için en önemli zemini öğretmenlik uygulaması sürecinin oluşturduğu söylenebilir (Alakuş, 2005:3).

Öğretmen adaylarının mesleki ve öz yeterlik algıları öğretmenlik uygulaması deneyimi ile şekillenmektedir (Danielewich, 2001:176). Öğretmenlik uygulaması öğretmen adayının eğitim gereksinimlerini fark etmesine, öğretim ilke ve yöntemlerini değerlendirmesine, kendi kararlarına ulaşmasına ve gerçek iş ortamıyla yüzleşmesine imkân sağlar. Dolayısıyla uygulama sürecinde aday öğretmenin mesleki gelişimine katkıda bulunularak düşünen, yansıtan ve kendini geliştiren bir öğretmen olmasının zemini oluşturulur (Yalın Uçar, 2012: 2638). Ayrıca öğrencilerin öğretmenliğe geçişte mesleğin tüm sorumluluğunu üstlenirken büyük bir olasılıkla yaşayabilecekleri ani stres ve olumsuz deneyimlerin (Flores ve Day, 2006: 225) önüne öğretmenlik uygulaması dersi sayesinde geçilmesi mümkün olabilecektir.

Ülkemizde 1998-1999 öğretim yılından itibaren, kuramsal ağırlıklı olan öğretmen eğitimi programlarında kuram ve uygulamada birliğin sağlanması amacıyla yeni çalışmalar başlatılmıştır (Alakuş, 2005: 4). MEB / YÖK Hizmet Öncesi Öğretmen Eğitimi Projesi kapsamında Eğitim Fakültesi - Uygulama Okulu İşbirliği programı oluşturulmuştur. Uygulamaya yönelik olarak 1998 tarihinde MEB ile YÖK arasında bir protokol imzalanarak öğretmen adaylarının MEB'e bağlı eğitim öğretim kurumlarında yapacakları öğretmenlik uygulamasına ilişkin bir yönerge yürürlüğe konulmuştur (YÖK, 2007). Öğretmen yetiştirme programlarında uygulamaya ayrılan zamanın önemli ölçüde artırılması ve bu sayede öğretmen adaylarının mesleğin gerektirdiği beceri ve deneyimi gerçek ortamda yani okullarda edinmesi öngörülmüş̧ür (YÖK, 1998). Öğretmen yetiştirme programlarında yapılan bu düzenlemeyle kuram ve uygulama 


\section{Z.Yıldırım Yakar-E.Uzun-B.Tekerek Öğretmenlik Uygulaması Dersi...}

derslerinin ağırlı̆̆g dengeli biçimde dağıtılmaya çalışılmış ve öğretmen adaylarının okul uygulamalarının süresi artırılarak içeriği açıkça belirlenmiştir (Topkaya ve Yalın, 2006: 15). 2006 yılında gerçekleşen program düzenlemesinde ise programlardaki kuramsal ders yükü artır1lırken uygulamanın kapsamı daraltılmıştır (Yıldırım, 2018). Son olarak 2017 yılında öğretmen yetiştirme lisans programlarında öğretmenlik uygulamalarının daha geniş bir zamana yayılarak ve daha yapılandırılmış bir şekilde gerçekleştirilmesi amacıyla tekrar düzenlemeler yapılmıştır. Yeni düzenlemeyle birlikte mevcut programlarda sadece bir dönem olan Öğretmenlik Uygulaması dersi tüm programlarda Öğretmenlik Uygulaması 1 ve Öğretmenlik Uygulaması 2 olarak iki döneme çıkarılmıştır (YÖK, 2018). Teorik ve pratik olmak üzere iki kısımdan oluşan Öğretmenlik Uygulaması dersinin işleniş süresinde ise değişikliğe gidilmeyerek altı ders saati uygulama okulunda, iki ders saati ise teorik olarak eğitim fakültesinde yürütülmesine devam edilecektir. Uygulama sürecinin daha sağliklı yürütülmesi amacıyla ilgili tüm birimlerin görüşleri alınarak "Öğretmen Adaylarının Millî Eğitim Bakanlığına Bağlı Eğitim Öğretim Kurumlarında Yapacakları Öğretmenlik Uygulamasına İlişkin Yönerge" üzerinde de güncelleme çalışmaları yapılmış ve yeni yönerge 2018 tarihinden itibaren yürürlüğe girmiştir.

Yalın Uçar (2008:2638)'a göre öğretmen eğitimi programları her ne kadar güncellenerek geliştirilse de öğretmenlik uygulamasında, ülke genelinde karşılaşılan birçok sorun nedeniyle süreç etkisizleşebilmekte ve dersin amacına ulaşılamamaktadır. $\mathrm{Bu}$ görüşü destekleyen çalışmalardan bazılarında, Öğretmenlik Uygulaması dersinin öğretmen adaylarının mesleki yeterliklerini artırma noktasında istenilen düzeyde katkıyı sağlayamadığı (Atmiş, 2013; Karadüz, Eser, Şahin ve İlbay, 2009; Petek, 2014), öğretmen adaylarının uygulama öncesi beklentilerinin karşılanabilme düzeyinin düşük olduğu (Aslan ve Sağlam, 2018; Atmiş, 2013) görülmüştür. Öğretmenlik Uygulaması dersinin tam anlamıla amacına ulaşamamasının; sınıf ve okul araç-gereçlerinin yetersizliği (Çepni ve Aydın, 2015; Demir ve Çamlı, 2011; Ergüneş, 2005), öğretmen adayı sayısının fazla olması, uygulama süresinin kısa olması (Akpınar, Çolak ve Yiğit, 2012; Baştürk, 2009; Turgut, Yılmaz ve Firuzan, 2008) uygulama okullarının fakültelerden uzaklığı (Kale, 2011) gibi fiziksel nedenleri olabileceği gibi literatürdeki çalışmalarda çok daha fazla vurgulanan aday öğretmenler, uygulama öğretmenleri, uygulama öğretim elemanları ve okul koordinatörlerinin yeterli bilgiye sahip olmamaları ve karşı1ıklı sorumluluklarını yerine getirmemeleri (Aytaç, 2010; Aytaçl1, 2012; Canbolat, 2014; Çepni ve Aydın, 2015; Değirmençay ve Kasap, 2013; Ergüneş, 2005; Görgen, Çokçalışkan ve Korkut, 2012; Ünver, 2003; Petek, 2014; Rakıcıŏlu-Söylemez, 2012; Yeşilyurt ve Semerci, 2012) gibi paydaşlardan kaynaklı nedenleri de olabilmektedir. 
Öğretmenlik uygulaması dersinde yaşanabilecek sorunlar, öğretmen adaylarının öğretmenlik mesleğine yönelik tutumlarının olumsuz yönde etkilenmesine ve öğretmenlik mesleğiyle ilgili eksik veya yanlış deneyimler edinmelerine sebep olabileceğinden öğretmenlik uygulaması dersinde yaşanabilecek sorunların tespitinin yapılması ve önlenmesi zorunludur. $\mathrm{Bu}$ doğrultuda yapacağımız bu araştırma ile 2017-2018 eğitim öğretim yılı fen bilgisi ögretmenliği ve sınıf öğretmenliği lisans programında dördüncü sınıfta yer alan öğretmenlik uygulaması dersi kapsamında uygulama okulu müdürü, uygulama okulu koordinatörü, uygulama öğretmeni, uygulama öğretim elemanı ve öğretmen adayları ile ilgili yaşanan sorunların ve çözüm önerilerinin yine her bir paydaşın birbirlerine yönelik görüşleri doğrultusunda belirlenmesi amaçlanmıştır.

Öğretmenlik uygulaması dersinin etkili olabilmesi paydaşların birlikte ortaya koyacakları işbirliği çalışmalarının niteliğiyle ilgilidir (Aydın ve Akgün, 2014: 4). Hâlbuki yapılmış birçok çalışmaya göre öğretmenlik uygulaması dersinde paydaşların etkili ve verimli bir işbirliğini tam olarak sağlayamadığı ve ögretmenlik uygulaması dersinde beklenen öğrenme çıktılarının gerçekleşemediği söylenebilir (Aytaç, 2010; Aytaçl1, 2012; Canbolat, 2014; Petek, 2014; Rakıcıŏlu Söylemez, 2012; Yeşilyurt ve Semerci, 2012). Karaca ve Aral (2011)'a göre uygulama okulları ile eğitim fakülteleri arasında bir uyum sağlanamamaktadır. Baştürk (2009)'ün araştırmasına göre de, öğretmen adayları ile uygulama öğretmenlerinin arasındaki karş11ıklı etkileşim çok az ve yüzeysel konularla sınırlı kalmaktadır. Aytaç (2010), öğretmenlik uygulaması dersi kapsamında uygulama öğretim elemanlarını çeşitli yönleriyle değerlendirmeyi amaçladığı çalışmasının sonucunda öğretmen adaylarına karşı uygulama öğretim elemanlarının rehberlik rolünü yerine getirme düzeylerinin yetersiz olduğunu belirlemiştir. Bunun yanı sıra, öğretmenlik uygulaması dersinin içerik ve amaçlarının ele alındığı seminer vb. etkinliklerin genel olarak yapılmadığı, yapılan etkinliklerin ise çoğunlukla, öğretmenlik uygulaması dersi ile ilgili genel bilgilerin verildiği kısa süreli toplantı, görüşme gibi etkinlikler ve dersin tanıtımına ilişkin kılavuzların sunumu ile sınırlı olduğu sonucuna ulaşılmıştır.

Yapılan literatür incelemesinde ilgili çalışmaların çoğunda, Öğretmenlik Uygulaması dersinde yaşanan sorunların daha çok bir veya iki paydaşın görüşleri doğrultusunda belirlenmeye çalışıldığ tespit edilmiştir (Atmiş, 2013; Aydın ve Akgün, 2014; Aytaç, 2010; Aytaçl1, 2012; Canbolat, 2014; Çetin ve Bulut, 2002; Demir ve Çamlı, 2011; Dursun ve Kuzu, 2008; Gökçe ve Demirhan, 2005; Kale, 2011; Karaca ve Aral, 2011; Paker, 2008; Yeşilyurt ve Semerci, 2011; Yılmaz, 2011). Yalın Uçar (2012) ise çalışmasında ilgili taraflardan öğretmen adayı, uygulama öğretmeni ve uygulama okulu yöneticilerinin görüşlerine yer vermiştir. Katranc1 (2008), uygulama öğretmenleri ve uygulama okulu koordinatörlerinin ders kapsamındaki görev ve sorumluluklarını yerine getirme düzeylerini 


\section{Z.Yıldırım Yakar-E.Uzun-B.Tekerek Öğretmenlik Uygulaması Dersi...}

belirlemek için uygulama okulu koordinatörleri, uygulama öğretmenleri ve aday öğretmenlerinin görüşlerini almıştır.

Öğretmenlik uygulaması dersinde paydaşlardan kaynaklı yaşanan sorunları yine tüm paydaşların görüşleri doğrultusunda inceleyen sinırlı sayıda çalışmaya rastlanmıştır (Seçer, Çeliköz ve Kayılı, 2010; Yeşilyurt ve Semerci, 2012). Bu nedenle yapacağımız çalışmanın ilgili alandaki mevcut bilgilere önemli katkı sağlaması ve araştırmanın sonucunda elde edilen bulguların öğretmenlik uygulaması dersinin daha verimli hale getirilmesinde ve Fakülte- Okul işbirliği sürecinin aksayan yönlerinin giderilmesinde yürütülecek çalışmalara 1şık tutması beklenmektedir. Ayrıca çalışma 2017-2018 eğitim öğretim yılında gerçekleştirilmiş ve bir yıl sonra ise "Öğretmen Adaylarının Millî Eğitim Bakanlığına Bağlı Eğitim Öğretim Kurumlarında Yapacakları Öğretmenlik Uygulamasına İlişkin Yönerge" üzerinde değişiklikler yapılarak 2018-2019 eğitim öğretim yılından itibaren yürürlüğe girmiştir. Yaptığımız çalışmadan elde edilen sonuçlar yeni yönetmelikte yapılan değişikliklerin paydaşların yaşadıkları sorunlar ve çözüm önerileri noktasında beklentileri karşılayıp karşılamadığını göstermesi açısından önemlidir.

Araştırmanın problem cümlesi olarak "Öğretmenlik Uygulaması dersinde öğretmen adayı, uygulama öğretim elemanı, uygulama öğretmeni, uygulama okulu koordinatörü ve uygulama okulu müdürünün her birinin diğer paydaşlarla ilgili olarak yaşadıkları sorunlar ve çözüm önerileri nelerdir?" şeklinde belirlenmiştir. Problem cümlesine uygun olarak belirlenen alt problemler aşağıdaki gibidir:

Öğretmenlik uygulaması dersinde ilgili paydaşların,

1. öğretmen adaylarıyla ilgili yaşadıkları sorunlar ve bu sorunlara yönelik önerileri nelerdir?

2. uygulama öğretmenleriyle ilgili yaşadıkları sorunlar ve bu sorunlara yönelik önerileri nelerdir?

3. uygulama öğretim elemanlarıyla ilgili yaşadıkları sorunlar ve bu sorunlara yönelik önerileri nelerdir?

4. uygulama okulu koordinatörleri ile ilgili yaşadıkları sorunlar ve bu sorunlara yönelik önerileri nelerdir?

5. uygulama okulu müdürleriyle ilgili yaşadıkları sorunlar ve bu sorunlara yönelik önerileri nelerdir? 


\section{YÖNTEM}

Öğretmenlik Uygulaması dersinde paydaşlarla ilgili olarak yaşanan sorunları ve çözüm önerilerini yine paydaşların görüşleri doğrultusunda tespit etmeye yönelik gerçekleştirilen bu araştırma nitel araştırma modeli olan bir durum çalışmasıdır. Nitel durum çalışmasında bir ya da birkaç durum derinlemesine araştırılır. Yani bir duruma ilişkin ortam, birey, olay, süreç vb. etkenler bütüncül yaklaşımla ele alınır ve ilgili durumu etkilemenin veya ilgili durumdan etkilenmenin nasıl olduğu incelenir (Yıldırım ve Şimşek, 2016: 73). Araştırmada nitel araştırmalarda sıkça kullanılan görüşme yöntemi kullanılmıştır.

\section{Çalışma Grubu}

Araştırmanın katılımcılarını; 2017-2018 Eğitim-Öğretim yılında bir devlet üniversitesinde Sınıf Öğretmenliği (SN)ve Fen Bilimleri Öğretmenliği (FB) lisans programının son sınıfında öğrenim gören toplam 19 öğretmen adayı (ÖA) ve öğretmenlik uygulaması dersi kapsamında görevlendirilen 8 uygulama öğretmeni (UÖ), 4 uygulama öğretim elemanı (UÖE), 4 uygulama okulu koordinatörü (UOK), 4 uygulama okulu müdürü (UOM) oluşturmaktadır. Araştırmanın katılımcıları araştırmaya gönüllü olarak katılmışlardır. Çalışmada katılımcıların görüş bildirdikleri paydaşların farklı olması sağlanmaya çalışılmıştır. Öğretim elemanlarının her biri farklı bir kurumdan sorumludur. Öğretmen adaylarının uygulamaya devam ettikleri kurum sayısının en az 8 olduğu belirlenmiştir. Öğretmen adayları ve öğretim elemanlarıyla görüşmeler akademisyen odalarında gerçekleştirilmiştir. Çalışmaya dâhil edilen uygulama öğretmenleri, uygulama okul koordinatörleri ve uygulama okul müdürleri ile 2 ilkokul (IO) ve 2 ortaokul (OO) olmak üzere 4 okulun her birinden eşit sayıda katılımcıyla görüşülmüştür. $\mathrm{Bu}$ katılımcılar ile bire bir görüşmeler kendi kurumlarında müdür ve müdür yardımcısı odalarında gerçekleştirilmiştir. Aşağıda katılımcılara ait bilgiler Tablo 1'de verilmiştir.

Tablo1. Katılımc1lara Ait Bilgiler

\begin{tabular}{lccccccccccc}
\hline & \multicolumn{1}{c}{} & \multicolumn{1}{c}{ ÖA } & \multicolumn{2}{c}{ UÖE } & \multicolumn{2}{c}{ UÖ } & \multicolumn{2}{c}{ UOK } & \multicolumn{2}{c}{ UOM } \\
\hline Paydaşlar/ & SN & FB & SN & FB & SN & FB & İO & OO & IO & OO \\
\hline Kadın & 6 & 8 & 2 & 1 & 2 & 2 & - & - & - & - \\
\hline Erkek & 5 & - & - & 1 & 2 & 2 & 2 & 2 & 2 & 2 \\
\hline Toplam & & 19 & & 4 & & 8 & & & 4 & & 4 \\
\hline
\end{tabular}

Katılımcılar kolay ulaşılabilir durum örneklemesi yöntemiyle belirlenmiştir. $\mathrm{Bu}$ yöntemde araştırmacı yakınında olan ve kolayca erişebileceği bir durumu 


\section{Z.Yıldırım Yakar-E.Uzun-B.Tekerek Öğretmenlik Uygulaması Dersi...}

seçer. Araştırmacının tanıdığı bir örneklem üzerinde çalışması daha pratik ve kolay olarak değerlendirilebilir (Yıldırım ve Şimşek, 2016: 123).

\section{Veri Toplama}

Araştırmada katılımcıların her biri için araştırmacı tarafından hazırlanan ve dört açık uçlu sorudan oluşan yarı yapılandırılmış görüşme formu kullanılmıştır. Görüşme formunun araştırma sorularına uygun olduğuna dair bir ölçme ve değerlendirme ve bir fen bilimleri eğitimi alanı uzmanının görüşleri alınmıştır. Görüssme yapılan kişilere önceden belirlenen bu sorular yöneltilmekle birlikte; görüşmenin gidişatına uygun olarak ek sorular yöneltilerek daha detaylı yanıtlar elde edilmeye çalışılmıştır. Yarı yapılandırılmış görüşmenin tercih edilme nedeni ise görüşülene kendini daha rahat ifade etme olanağı sunması ve gerektiği durumda derinlemesine bilgiye ulaşma imkânı vermesidir (Büyüköztürk vd., 2016: 154). Görüşmelerden elde edilen veriler katılımcıların rızasıyla kayıt altına alınmıştır. Katılımcılarla yapılan görüşme süresi ortalama olarak 20 dakika sürmüştür. Görüşmeler katılımcıların kendilerini rahat ifade etmeleri için sessiz bir ortamda yapılmıştır. Katılımcıların diğer paydaşlarla ilgili yaşadıkları sorunları rahatlıkla dile getirebilmeleri için herhangi bir kişisel bilgi talep edilmemiştir. Katılımcılara yanıtlarını açmaları için ipuçları verilmekle beraber herhangi bir yönlendirici tepki verilmekten kaçınılmış ve yansız bir tavır sergilenmiştir.

\section{Verilerin Çözümlenmesi}

Yarı yapılandırılmış görüşmelerden elde edilen verilerin analizinde içerik analizi kullanılmıştır. Görüşme kayıtları yazılı metne dönüştürülerek elde edilen veriler kavramsallaştırılmıştır. $\mathrm{Bu}$ aşamada veriler içinde anlamlı bulunan bölümler için en uygun olan kavram (kod) bulunmaya çalışılmıştır. Daha sonra verileri genel düzeyde açıklayan ve yapılan kodlamaları belirli kategorilerde toplayan temalar belirlenmiş̧tir. Bu süreci çalışmada yer alan üç araştırmacı birlikte gerçekleştirmiş ve yapılan kodlamalarla ilgili görüş birliği sağlanmıştır. Kodlama ve tematik kodlamalar ışığında veriler düzenlenmiş ve sunulmuştur. Son aşamada ise elde edilen bulgular yorumlanarak çıkarımlarda bulunulmuştur.

\section{BULGULAR}

Öğretmen adayları ile ilgili yaşanan sorunlar ve çözüm önerilerine ait bulgular

Aşağıda Şekil 1'de "öğretmen adayları" temasında yer alan "öğretmen adayları ile ilgili sorunlar" ve "öğretmen adaylarına yönelik öneriler" alt temalarına ilişkin kavramsal kodlamalar gösterilmiştir. 


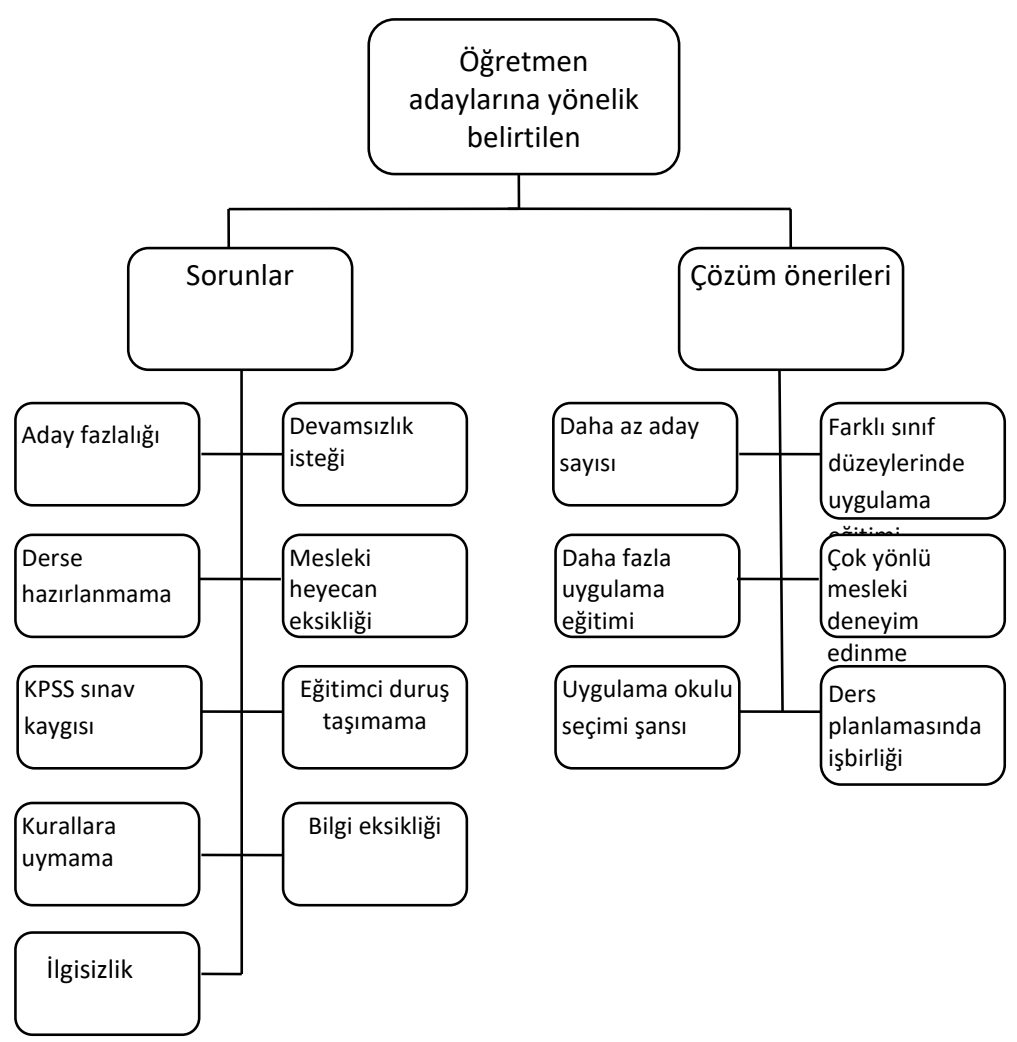

Şekil 1. Öğretmen Adaylarına Yönelik Belirtilen Sorunlar ve Çözüm Önerileri

Uygulama öğretmenleri sorumlu oldukları öğretmen adaylarının sayı anlamında çok olmasından (6) ve derslere hazırlıksız gelmelerinden (2) dolayı sıkıntı yaşadıklarını belirtmişlerdir. Bu sorunların çözümü için uygulama öğretmenleri sorumlu oldukları öğretmen adayı sayısının azaltılması gerektiği (4) yönünde öneride bulunmuşlardır.

Öğretim elemanları öğretmenlik uygulaması dersinde öğretmen adayları ile işbirliği konusunda problemler yaşadıklarını (1) ve bu problemlerin daha çok KPSS kaygısından kaynaklı olduğunu ifade etmektedirler. Bu sorunlara çözüm olarak ise öğretmenlik uygulaması dersinin lisansın ilk yıllarından itibaren verilmesi gerektiğini (1) belirtmişlerdir.

Okul koordinatörlerinin öğretmen adayları ile ilgili olarak; izin alma isteği(1), eğitimci duruşu yansıtmama (1), mesleki heyecanı yaşamama (1), idari işlemlerle ilgili bilgi almama (1) ve okula geç gelme(1) gibi noktalarda sorunlar yaşadıklarını belirtmişlerdir. Öğretmen adaylarının uygulama yapacakları okulu 


\section{Z.Yıldırım Yakar-E.Uzun-B.Tekerek Öğretmenlik Uygulaması Dersi...}

tercih edebilmeleri (1), ders dışı mesleki çalışmalara da katılmaları (1) ve tüm sınıf seviyelerinde derslere katılmaları (1) şeklinde önerilerde bulunmuşlardır. Okul müdürleri ise her öğretmene düşen öğretmen adayı sayısının çok olmasından (1) ve öğretmen adaylarının öğretmenlik uygulaması dersi ile ilgili yeterli bilgi sahibi olmamalarından (1) ve öğretmenlik mesleğine yönelik ilgilerinin düşük olmasından (1) dolayı sorunlar yaşadıklarını belirtmiştir. Okul müdürleri öğretmen adayı sayısının azaltılması (1) ve uygulama okulu ve üniversitenin ders planlamalarında koordineli çalışılması gerektiğini (1) vurgulamıştır.

Paydaşların öğretmen adaylarıyla ilgili olarak dile getirdikleri sorun ve çözüm önerilerinden örnek ifadelerden bazıları şöyledir: (UOM-1) "altı öğrencinin aynı anda sinıfta olması bir dezavantaj. Biz istiyoruz ki sayı ikiye indirilsin, daha aktif daha faal olsunlar". UOK-2 "bu sene çok yaşamadık ama sürekli bahane uydururlardı izin almak için. Deneme sınavım vardı, dershaneye gideceğim gibi burayı önemsememe gibi durumları oluyordu". UÖ-4 "bana göre beş öğrenci fazlaydı. İki ya da üç olabilir. Çünkü o zaman öğretmen adayına daha fazla zaman ayırabileceğiz, daha çok ders anlattıracağız...” UOK-1: “...okul yönetimiyle ilgili bu işleri nasıl yapıyorsunuz gibi bizden hiçbir bilgi istekleri olmadı”.

\section{Uygulama öğretmenleri ile ilgili yaşanan sorunlar ve çözüm önerilerine ait bulgular}

Aşağıda Şekil 2'de "uygulama öğretmeni" temasında yer alan "uygulama öğretmenleri ile ilgili sorunlar" ve "uygulama öğretmenine yönelik öneriler" alt temalarına ilişkin kavramsal kodlamalar gösterilmiştir.

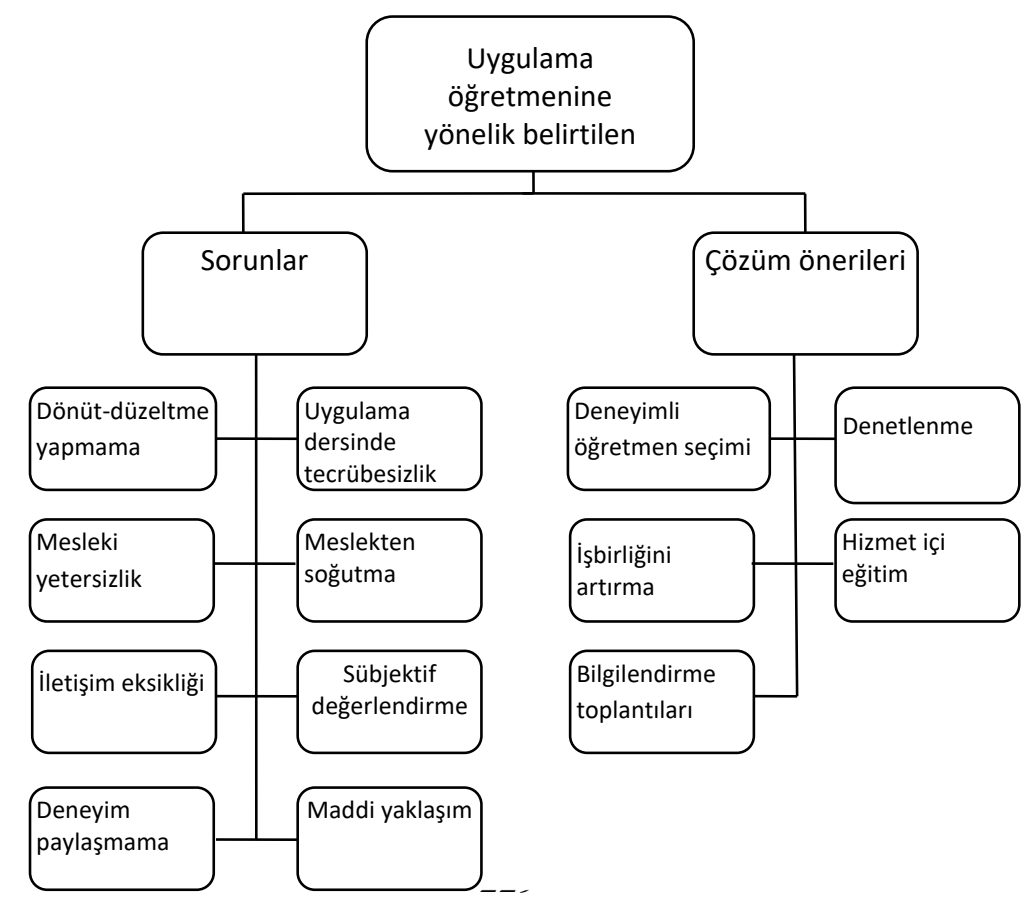




\section{Şekil 2. Uygulama Öğretmenine Yönelik Belirtilen Sorunlar ve Çözüm Önerileri}

Öğretmen adaylarının uygulama öğretmenleriyle en çok sorun yaşadıklarını düşündükleri noktalar; ders anlatımı öncesi ve sonrasında dönüt ve düzeltmelerde bulunmaması (16), öğretim yöntem ve tekniklerini sınırlı kullanması (10), öğretmen adaylarıyla etkili iletişim kuramaması (7) olarak belirlenmiştir. Ayrıca öğretmen adayları, uygulama öğretmenlerinin tecrübelerini kendileriyle paylaşmaması, derslerde kendilerini sınıfta yalnız bırakması, ders dışı etkinliklere kendilerinin katılımına destek vermemesi gibi konularda da sıkıntı yaşadıkları yönünde görüş bildirmişlerdir. $\mathrm{Bu}$ sorunlara yönelik öğretmen adaylarının sunmuş olduğu çözüm önerileri yeterli bilgi ve tecrübesi olan uygulama öğretmeni seçimi (10), uygulama öğretmenlerinin denetlenmesi (4), öğretmenlik uygulaması dersi ile ilgili sorumluluklarını bilme (4), öğretim elemanlarıyla işbirliği içinde olma şeklinde sıralanabilir.

Öğretim elemanları, uygulama öğretmenlerinin kendileriyle yeterince işbirliği yapmadıklarını (1) ifade etmişlerdir. Bunun nedeni ise üniversite ve MEB arasında iyi bir koordinasyonun olmayışını ve öğretmenlerin bu dersi iş yükü olarak görerek önemsemeyişini görmektedirler. Bu sorunların çözümü için kurumlar arası işbirliğginin sağlanması gerektiğini (1) ve öğretmen adaylarının dersle ilgili sorumluluklarının vurgulanacağı toplantıların koordinatörler tarafından düzenlenmesi (1) gerektiğini ifade etmişlerdir.

Okul koordinatörlerinin uygulama öğretmenleri ile ilgili yaşadığı sorunlar incelendiğinde, öğretmenlik uygulaması dersi ile ilgili tecrübe eksikliği (1), öğretmen adaylarının değerlendirmesinin objektif olmaması (1), öğretmen adaylarına rehberlikte yetersiz olabilme (1) ve öğretmenlik mesleğine yönelik olumsuz tutum geliştirmelerine neden olabilme (1) gibi sorunlar olduğu tespit edilmiştir. Süreci sağlıklı yürüten öğretmenler ile eğitim verilmesi (1) ile bu sorunların çözüme kavuşabileceğini belirtmişlerdir.

Okul müdürleri, uygulama öğretmenlerin yalnızca ek ders mantığıyla görev alma isteğinin olabilmesi (1) ve öğretmenlik uygulaması dersi ile ilgili görevlerini tam anlamıyla bilmemeleri (1) yüzünden sorunlar olduğunu söylemiştir. Bununla ilgili olarak deneyimli öğretmenlerin görevlendirilmesi (1) ve bu öğretmenlere öğretmenlik uygulaması dersi hakkında detaylı bilgilendirilme yapılması gerektiğini (1) belirtmişlerdir.

Paydaşların uygulama öğretmenleriyle ilgili olarak dile getirdikleri sorun ve çözüm önerilerinden bazı örnek ifadeler şöyledir: ÖA-10: “ bütün dersleri dört kişi gittiğimiz için biz anlattık. Hocanın anlatımını gözlemleyemiyorduk. Biz anlattıktan sonra o da anlatsaydı farkını görebilirdik."UOM-1: "Şu çok doğru değil; diğer öğretmenlerde ek ders alsın. Niye hep o öğretmen, biz daha iyi 


\section{Z.Yıldırım Yakar-E.Uzun-B.Tekerek Öğretmenlik Uygulaması Dersi...}

yaparız gibi yaklaşımlar mutlaka olacaktır... Buna çözüm olarak hizmet içi yoluyla yetiştirilmiş öğretmenler bence bu işi yürütmeliler.”ÖA-1: "uygulama öğretmeni hiçbir şey bilmiyor. Ne yapacağımızı bizden öğrenmeye çalışıyordu."UOK-1: “meslekten bıkkınlık gelenler yaşadığı olumsuz şeyleri anlatıyor. Tabi stajyer öğretmende ister istemez etkileniyor... Bilgi, birikimini aktarabilecekler seçilmeli.”

\section{Uygulama öğretim elemanları ile ilgili yaşanan sorunlar ve çözüm önerilerine ait bulgular}

Aşağıda Şekil 3'de "uygulama öğretim elemanları" temasında yer alan "uygulama öğretim elemanları ile ilgili sorunlar" ve "uygulama öğretim elemanlarına yönelik öneriler" alt temalarına ilişkin kavramsal kodlamalar gösterilmiştir.

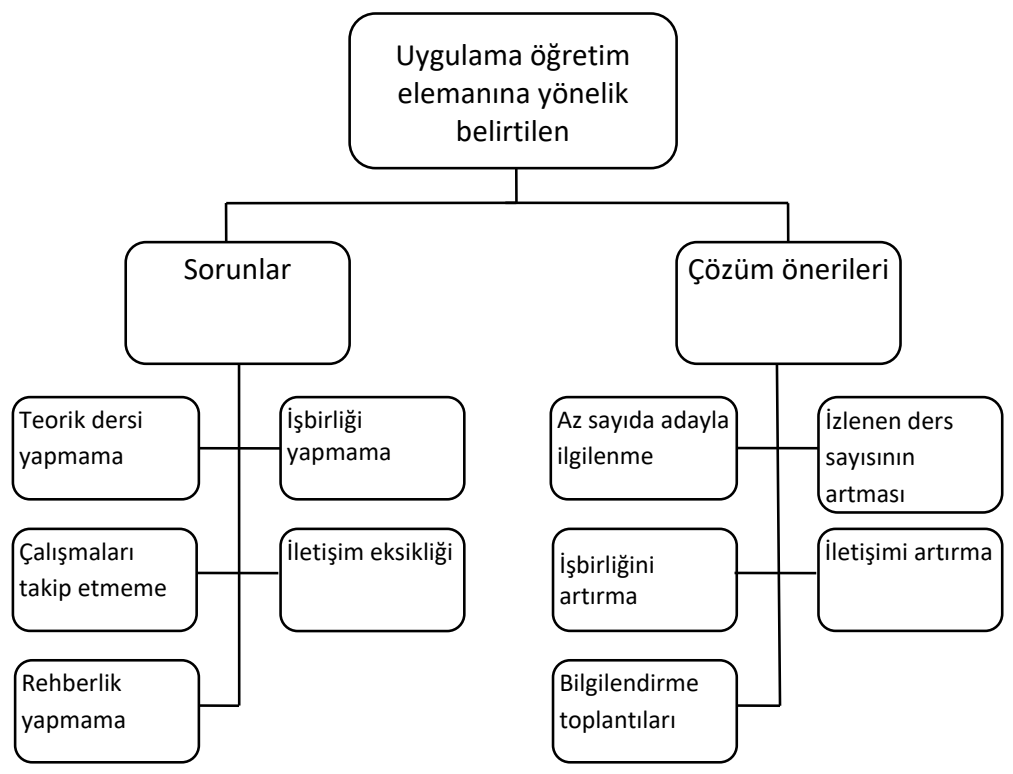

Şekil 3. Uygulama Öğretim Elemanına Yönelik Belirtilen Sorunlar Ve Çözüm Önerileri

Öğretmen adaylarının, öğretim elemanlarıyla ilgili yaşadıkları sorunlar incelendiğinde; ders anlatımı öncesinde hazırlanan ders planı ve raporlarını incelememe (19), uygulama okulunda ders sunumunu izlememe (8), dönem başında uygulama okulundaki tanışmaya rehberlik etmeme (8) ve üniversitede ki teorik dersleri yerine getirmeme (7) gibi sorunlarla sıkça karşılaşıldığ görülmektedir. Bu sorunlarla ilgili öğretmen adayları, öğretim elemanlarının 
sorumlu olduğu öğretmen adayı sayısının azaltılması (7), öğretmenlik uygulaması dersi için yeterli deneyime ve bilgiye sahip olması (5) ve yapılan uygulamalarla ilgili öğretim elemanları arasında tutarlılık olması gerektiğini vurgulamaktadırlar.

Uygulama öğretmenleri, uygulama öğretim elemanlarıyla ilgili yaşadıkları sorunlar, okula tanışmaya gelmeme ve iletişim kurmama (5), öğretmen adaylarının dersteki gelişimini takip etmeme (4), öğretmen adaylarının değerlendirmesinde işbirliği yapmama (4) ve öğretmen adaylarını okulda ders anlatımını dinlemeye gelmeme(4) şeklinde sıralanabilir. Uygulama öğretmenleri bu sorunlara çözüm olarak öğretim elemanlarının okullarda öğretmen adaylarının ders anlatımlarını daha çok izlemeleri (4) ve öğretmen adaylarının değerlendirilmesinde öğretmenlerle işbirliği yapmaları (2) gerektiğini belirtmişlerdir.

Okul koordinatörlerinin uygulama öğretim elemanlarıyla ilgili problemleri, öğretmen adaylarını tanışmaya getirmemeleri (1), koordineli çalışmalar yapmamaları (1) ve iletişim kurmada eksikliklerinin olması (1) şeklinde sıralanabilir. Bu sorunların sağlıklı iletişim, belirli zamanlarda düzenlenecek toplantılar ve işbirliği ile çözüme kavuşabileceğini (2) ifade etmişlerdir. Benzer şekilde okul müdürleri, ögretim elemanlarının kendileriyle iletişim kurmadıklarını (1) ve okula yeterince gelmediklerini (2) ifade etmişlerdir. Müdürler, öğretim elemanlarının öğretmenlik uygulaması dersi sürecine daha etkin şekilde katkıda bulunmaları (2) gerektiğini ifade etmişlerdir.

Paydaşların öğretim elemanlarıyla ilgili olarak dile getirdikleri sorun ve çözüm önerilerinden bazı örnek ifadeler şöyledir: ÖA-9: "Üç dönemdir okula gidiyorum. Sadece bir defa dinlenmeye gelindi ve sadece beş dakika karşısında ders anlatmama müsaade edildi.” ÖA-5 “programı çok yoğun olduğundan kısmen rehberlik yaptı. Yüksek lisans öğrencilerim var, derslerim var size vakit ayıramıyorum dedi." UOM-1: "Başta bir plan program yapmaları gerekir bizimle koordineli bir şekilde.” UOK-2: “öğretmenlerimize rehberlik yapıp görüş alışverişinde bulunmalılar. Üniversitedeki işlerinden zaman ayıramadılar. Bunun düzelmesi gerekir.”

Okul koordinatörleri ile ilgili yaşanan sorunlar ve çözüm önerilerine ait bulgular

"Uygulama okul koordinatörü" temasında yer alan "uygulama okul koordinatörü ile ilgili sorunlar" ve "uygulama okul koordinatörüne yönelik öneriler” alt temalarına ilişkin kavramsal kodlamalar aşağıda Şekil4'te gösterilmiştir. 


\section{Z.Yıldırım Yakar-E.Uzun-B.Tekerek Öğretmenlik Uygulaması Dersi...}

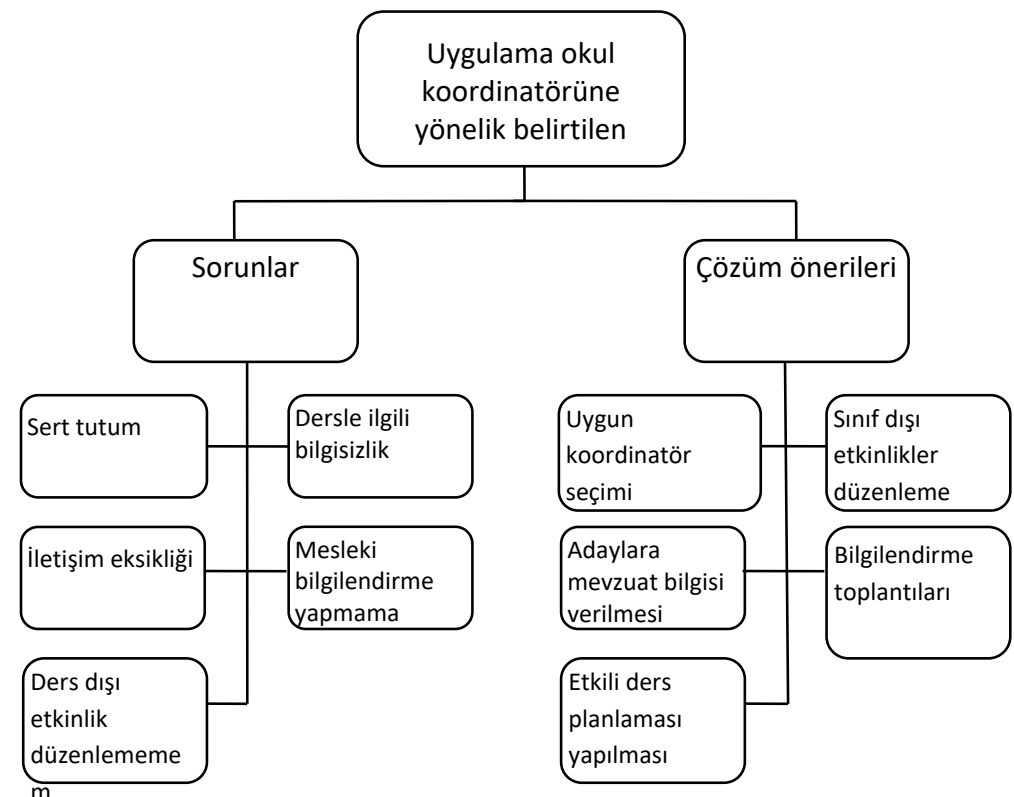

Şekil 4. Uygulama Okul Koordinatörüne Yönelik Belirtilen Sorunlar ve Çözüm Önerileri

Uygulama okul koordinatörü ile ilgili sorunlara bakıldığında öğretmen adayları beş noktada sorun yaşadıklarını belirtmişlerdir. Bunlar; ders dışı etkinliklere katılımı sağlamama (13), aday öğretmenlerle devam durumu dışında iletişim kurmama (10), fazla otoriter tutum sergileme (7), öğretmenlik uygulaması dersi ile ilgili bilgi sahibi olmama (5) ve öğretim programı ve mevzuatın uygulanmasıyla ilgili bilgilendirme yapmama (4) olarak ortaya çıkmıştır. Öğretmen adayları uygulama okul koordinatörleriyle ilgili yaşadıkları sorunların önlenmesi için bazı önerilerde bulunmuşlardır. Bunları: uygulama okul koordinatörünün iletişim düzeyi yüksek ve gönüllü müdür yardımcılarından seçilmesi (8), öğretim programı ve mevzuatın uygulanmasıyla ilgili bilgilendirme yapmaları (5) ve ders programlarını öğretmen adaylarının farklı öğretmenlerin derslerini gözlemleyecek şekilde planlamaları (4) olarak ifade etmişlerdir.

Uygulama öğretmenleri, okul koordinatörleri ile ilgili olarak, öğretmenlik uygulaması dersi kapsamında öğretmen adaylarıyla birlikte sınıf dışı etkinlik planlama ile ilgili sorun yaşadıklarını ifade etmişlerdir. Öneri olarak; okul koordinatörlerinin sınıf dışı etkinlikler planlaması (3), iletişim becerisine sahip 
müdür yardımcılarının koordinatör olması (1) ve öğretmenlik uygulaması dersi ile ilgili akademik dönem başlamadan önce bilgilendirme toplantılarının yapılması gerektiği belirtilmiştir (1).

Öğretim elemanları, okul koordinatörlerinin derse giren öğretmen adayı sayısında iyi bir planlama yapmaması sonucu dersin veriminin düştüğünü (1) belirtmişlerdir. $\mathrm{Bu}$ konuda okul koordinatörlerinin düzenleme yapmaları gerektiğini öneri olarak belirtmişlerdir. Okul müdürleri ise okul koordinatörlerinin süreçle ilgili tecrübesiz olmalarından (1)kaynaklı sorun yaşadıklarını söylemişlerdir. Öğretmenlik uygulaması dersi ile ilgili olarak tecrübe sahibi olan okul koordinatörleriyle çalışmanın süreci rahatlatacağını belirtmişlerdir.

Paydaşların uygulama okul koordinatörleri ilgili olarak dile getirdikleri sorun ve çözüm önerilerinden bazı örnek ifadeler şöyledir: ÖA-8: “Giderdik imza atmaya yanlarına imza kâğıdını gösterirdi. Merhaba işte, görüşürüz gibisinden konuşulurdu sadece. Yani herhangi bir konuda yardımc1 olmadılar, yol göstermediler.” ÖA-1: “çoluk çocuk, gelsin gitsin gözüyle bakılıyor. Stajyerler sayg1 ve değer görmüyor.”ÖA-5: “...bizi toplasa odasında sorunları belirlese, şu konuda bana gelebilirsiniz, size şu şekilde yardımcı olabilirim tarzı söylemlerde bulunsaydı daha etkili olabileceğini düşünüyorum.”UÖ-4: "işbirliği içinde sınıf dışında da bazı etkinlikler yapmada öğrencileri dâhil etmemiz onlara yararlı olur diye düşünüyorum."

\section{Okul müdürleri ile ilgili yaşanan sorunlar ve çözüm önerilerine ait bulgular}

"Uygulama okul müdürü" temasında yer alan "uygulama okul müdürü ile ilgili sorunlar" ve "uygulama okul müdürüne yönelik öneriler" alt temalarına ilişkin kavramsal kodlamalar aşağıda Şekil 5’te gösterilmiştir. 


\section{Z.Yıldırım Yakar-E.Uzun-B.Tekerek Öğretmenlik Uygulaması Dersi...}

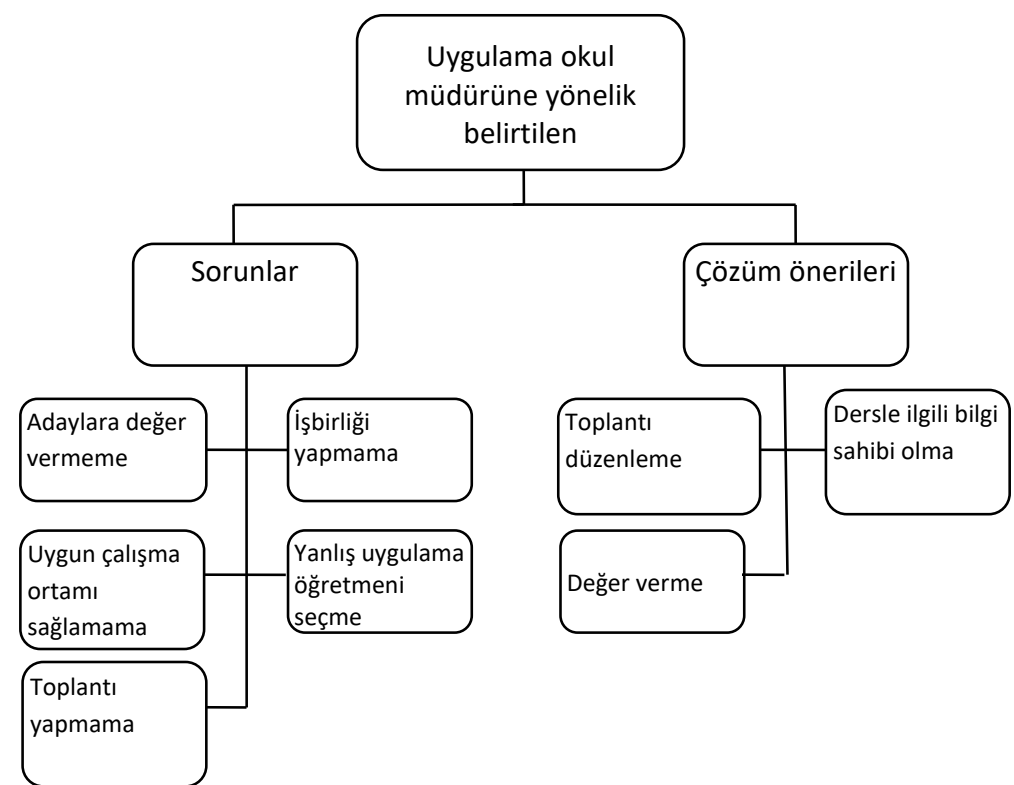

Şekil 5. Uygulama Okul Müdürüne Yönelik Belirtilen Sorunlar ve Çözüm Önerileri

Öğretmen adaylarının uygulama okul müdürleriyle yaşadıkları sorunlara bakıldığında; öğretmenlik uygulaması dersi ile ilgili bilgilendirme toplantısı yapmama (18), öğretmen adaylarına kendilerini okulun bir parçası olarak hissettirmeme (4) ve okulda ögrretmen adaylarının çalışabilmesi için uygun ortamı hazırlamama şeklinde problemlerle karşılaşıldığı belirlenmiştir. $\mathrm{Bu}$ sorunlara karşı öğretmen adayları, okul müdürlerinin kendileriyle belli aralıklarla toplantılar yapmalarını (9) ve kendilerini değerli hissetmelerini sağlayacak etkinliklerde bulunmaları(3) gibi önerilerde bulunmuşlardır.

Uygulama öğretmenleri, okul müdürlerinin öğretmenlik uygulaması dersi ile ilgili toplantılar düzenlemediklerini belirtmişlerdir. Öneri olarak öğretmenler, okul müdürlerinin paydaşları bir araya getiren toplantı yapmaları (3) ve öğretmen adaylarının kuruma adapte olmalarını sağlayacak çalışma yapmaları (4) gerektiğini belirtmişlerdir.

Öğretim elemanlarının okul müdürleri ile ilgili yaşadığı sorunlar incelendiğinde ise, müdürlerle işbirliği kurmada zorluk yaşadıklarını (1) ve müdürler tarafindan seçilen uygulama öğretmenlerinden yeterli verimin alınamadığını (1) belirtmişlerdir. Öğretim üyeleri bu sorunlara çözüm olarak öğretmenlik uygulaması dersinde öğretmen adaylarıyla ilgilenecek öğretmenlerin 
seçiminde müdürler ve öğretim üyelerinin birlikte karar vermeleri gerektiğini söylemişlerdir.

Okul koordinatörleri, okul müdürlerinin öğretmenlik uygulaması ile ilgili bilgi sahibi olmamalarını (1) ve resmi toplantılar düzenlememelerini (1) sorun olarak belirtmişlerdir. $\mathrm{Bu}$ hususlarda alınacak önlemlerin (1) sorunları gidereceğini ifade etmişlerdir.

Paydaşların uygulama müdürleri ile ilgili olarak dile getirdikleri sorun ve çözüm önerilerinden bazı örnek ifadeler şöyledir: ÖA2: “Algılarını değiştirmeleri lazım stajyeriz diye bize sadece öğrenci gözüyle bakıyorlar. Odasına bir kere gitmişliğim bile yok." ÖA-7: "kendisiyle hiç tanışmadım, görmedim de.”UOK1: "Önceden zaman kaybetmeden müdürlerle toplantılar yapılmalı. Yapılması gerekenler kalabalık olmayacak şekilde sade şekilde...okul müdürü ne yapacağını bilmeli." UÖ-3: “öğretmenler olsun koordinatör, müdür bir araya gelip on dört haftayı nasıl verimli hale getiririz diye konuşmalılar."

\section{TARTIŞMA VE SONUÇ}

2018 yılında "Öğretmen Adaylarının Millî Eğitim Bakanlığına Bağlı Eğitim Öğretim Kurumlarında Yapacakları Öğretmenlik Uygulamasına İlişkin Yönerge”, Milli Eğitim Bakanlığı'nın ilgili birimleri, Yükseköğretim Kurulu Başkanlığı, eğitim fakülteleri ve il millî eğitim müdürlüklerinin görüşleri doğrultusunda güncellenmiş olup bu araştırma 2017-2018 öğretim y1lında mevcut olan yönerge doğrultusunda yürütülen öğretmenlik uygulaması dersi kapsamında gerçekleştirilmiştir. Dolayısıyla bu araştırmanın amaçları arasında yer almasa da yapılan görüşmelerde tespit edilen paydaşların yaşadıkları bazı sorunların güncellenen yönergede yapılan değişikliklerle ne oranda çözüme kavuşturulduğunu yorumlama olanağ

Yapılan görüşmelerde, katılımcıların "öğretmenlik uygulaması" dersinin tam olarak amacına ulaşmaması ile ilgili dile getirdikleri sorunlardan bazılarının doğrudan paydaşların kendilerinden kaynaklı olduğu bazılarının ise yönerge kaynaklı olduğu anlaşılmıştır. Paydaşların görev ve sorumlulukların yerine getirilmemesinde etkili olduğunu düşündükleri hususların başında bir öğretim elemanının 12, uygulama öğretmeninin 6 öğretmen adayına rehberlik etmesi ve uygulama süresinin yeterli olmayışı gelmektedir. Görüşmelerde, rehberlik edilen öğretmen adayı sayısının azaltılması yönündeki isteklerin güncellenmiş yönergede karşılık bulduğu görülmektedir. Güncellenen yönergede her öğretim elemanına düşen öğrenci sayısı 8 , her uygulama öğretmeni başına düşen öğrenci sayısı 4 olarak değiştirilmiştir. Yönergede öğretim elemanlarının uygulama öğrencilerinin dersine her dönem en az dört kez katılması yönündeki değişiklik bu çalışmada öğretim elemanları ile ilgili yaşandığ 1 tespit edilen sorunların başında gelen adayların gelişimini yeterince takip etmeme durumunun önlenmesi 


\section{Z.Yıldırım Yakar-E.Uzun-B.Tekerek Öğretmenlik Uygulaması Dersi...}

adına olumlu bir değişikliktir. Ayrıca sadece bir dönem yürütülen öğretmenlik uygulaması dersinin süresi uzatılarak iki dönem olarak gerçekleştirilmesi ve uygulama öğrencisinin toplamda en az 24 saat fiilen ders anlatması yönünde olumlu değişiklikler yapılmıştır. Bu yönergenin uygulamada olmadığı 2017-2018 öğretim yılında gerçekleştirilen araştırmadan elde edilen sonuçlar ve bunlara ilişkin aşağıda verilmiştir.

yapılan tartışmalar

Öğretmenlik uygulaması dersi kapsamında ilgili paydaşların birbirleri ile ilgili yaşadıkları sorun ve çözüm önerilerinin incelendiği araştırmada, sayılarının fazlalığı dışında öğretmen adayları ile ilgili fazla olumsuz görüş belirtilmemiştir. Düşük oranda da olsa paydaşların sorun olarak bahsettikleri ders hazırlığının olmaması, mesleki tutum ve davranış sergilememe, ders dışı mesleki deneyimlerde isteksizlik gibi durumların benzer çalışmalarda (Arıkan, 2009; Görgen, Çokçalışkan ve Korkut, 2012; Gündoğdu, Altın, Üstündağ ve Altay, 2018; Güzel, Berber ve Oral, 2010; Yılmaz ve Naml,, 2017) tespit edildiği anlaşılmaktadır. Gündoğdu, Altın, Üstündağ ve Altay (2018) in yaptıkları çalışmada öğretmen adaylarının ders planı ve materyal hazırlamada yetersiz oldukları sonucuna ulaşılmıştır. Gümüş ve diğerlerinin (2018) çalışmasının sonucuna göre uygulama öğretmenlerinin bir kısmı öğretmen adaylarının uygulamada motivasyonlarının düşük olduğunu belirtmektedir. Akpınar, Çolak ve Yiğit (2012) tarafından öğretmen adaylarının yeterliği konusunda yapılan çalışmada, öğretmen adaylarının iletişim becerisinin yetersizliği üzerinde durulmuştur.

Katılımcılar öğretmen adaylarıyla ilgili olarak, uygulama yapacakları okulu kendilerinin araştırarak tercih etmelerinin sağlanması ve ders dışı mesleki tecrübe edinmeleri yönünde çalışmaların yapılması gibi önerilerde bulunmuşlardır.

Uygulama öğretmenleri ile ilgili en fazla sorun yaşadığı belirlenen ilgili paydaş öğretmen adaylarıdır. Öğretmen adayların çoğunluğu uygulama öğretmenlerinin kendilerine gerekli rehberliği sağlayamadığını düşünmektedirler. Gerekçe olarak da derslerde daha çok geleneksel öğretim metotlarını kullanmalarını, ders hazırlıklarını incelememelerini, kendilerine dönüt düzeltmelerde bulunmamalarını, değerlendirmelerinin güvenilir olmamasını, sağlıklı iletişim kurmamalarını öne sürmüşlerdir. Öğretmen adayları, uygulama öğretmenleri ile ilgili yaşanan sorunlara çözüm olarak ögretmenlik uygulaması dersinde yeterliği olan tecrübeli ve gönüllü öğretmenlerin görevlendirilmesini, yaptıkları çalışmaların denetlenmesini ve öğretim elemanlarıyla işbirliği içinde çalışmaları yürütmelerinin sağlanmasını önermişlerdir. Çalışmanın bulgularını destekleyen Aydın ve Akgün (2014)'ün çalışmasında da öğretmen adayları, uygulama öğretmenlerinin kendileriyle yeterince ilgilenmediğini, ders anlatımlarında yalnız bırakıldıklarını, dönütler 
alamadıklarını ve anlatacakları ders için yeterliliklerinin olup olmadığını dikkate almadıklarını belirtmişlerdir. Süral (2017)'a göre uygulama öğretmenlerinin öğretmen adaylarına mesleki rehberlik düzeyleri beklentilerin altında kalmaktadır. Aytaçlı (2012)'nın öğretmenlik uygulamasını değerlendirdiği çalışmasının sonucunda da öğretmen adaylarına göre uygulama öğretmenlerinin dersleri gözlemleme oranı oldukça düşük olup sorumluluklarını yeterince yerine getirmemektedirler. Bu nedenle uygulama öğretmenlerinin denetlenmesinin ve görevlendirilmelerinin daha titizlikle yapılması gerektiğini önermektedirler. Araştırmanın sonucundan farklı olarak öğretmen adaylarının uygulama öğretmenleri ile ilgili olumlu görüş bildirdiği çalışmalarda mevcuttur. Akyıldız (2018)'ın çalışmasından elde edilen bulgularda uygulama öğretmenlerinin görev ve sorumluluklarından bazılarını her zaman yerine getirdikleri, bazılarını ise çoğunlukla yerine getirdikleri sonucu elde edilmiştir. Yine Kökçü (2015)'nün çalışmasında öğretmen adayları uygulama öğretmenlerinin kendilerine katkı sağladığını ve tecrübelerinden yararlandıklarını fakat etkili iletişim noktasında sorunlar yaşadıklarını söylemişlerdir.

Öğretim elemanları, okul koordinatörleri ve okul müdürleri uygulama öğretmenleriyle ilgili fazla bir sorun dile getirmeseler de öğretim elemanları kendileriyle yeterince işbirliği kurulmadığ 1 ve dersin fazla önemsenmediği durumlarla karşılaştıklarını belirtmişlerdir. Okul koordinatörleri ve okul müdürleri de uygulama öğretmenlerinin bazılarının dersle ilgili fazla bilinçli olmadığını, öğretmen adaylarını objektif değerlendiremeyebildiklerini ve mesleğe yönelik olumsuz tutum gelişimine sebep olabildiklerini söylemişlerdir. Çözüm önerisi olarak ise deneyimli olan ve süreci sağlıklı götürebilenlerin görevlendirilmesi, düzenli olarak bilgilendirme toplantıları yapılması gerektiği dile getirilmiştir. $\mathrm{Bu}$ çalışmada okul idarecilerinin uygulama öğretmenlerinin genelinin sorumluluklarını yerine getirdiğini bazen sorunlu durumlar yaşandığını belirtmeleri Katrancı (2008)'nın çalışmasının sonuçlarıyla benzerlik göstermektedir. Katrancı (2008)'nın çalışmasına göre okul koordinatörleri uygulama öğretmenlerinin görev ve sorumluluklarını yeterince yerine getirdiklerini düşünmektedirler.

Görüşmelerde öğretim elemanlarıyla ilgili diğer tüm paydaşların yaşadıklarını söyledikleri sorunların başında iletişim kurmamaları, tanışmak için okula gelmemeleri, öğrencilerin uygulamada gelişimini yeterince takip etmemeleri, ders anlatımlarını yeterince gözlemlememeleri gelmektedir. Ayrıca uygulama öğrencilerinin büyük bir kısmı öğretim elemanlarının teorik dersleri işlemediklerini, ders hazırlıklarını ve raporlarını takip etmediklerini belirtmişlerdir. Öğretim elemanlarıyla ilgili olarak elde dilen bu sonuçlara Çepni, Aydın ve Şahin (2015), Akyıldız (2018), Bural ve Avşaroğlu (2012), Yeşilyurt ve Semerci (2011), Kale (2011) ve Yıldız (2012)'ın çalışmalarında da ulaşılmıştır. $\mathrm{Bu}$ çalışmada uygulama öğrencilerinin çoğunluğu öğretim 


\section{Z.Yıldırım Yakar-E.Uzun-B.Tekerek Öğretmenlik Uygulaması Dersi...}

elemanlarının derse önem vermediği yönünde görüşler bildirmişlerdir. Seçer, Çeliköz ve Kayılı (2010)'nın öğretmenlik uygulaması dersinde yaşanan sorunları incelediği çalışmasında ise öğretmen adaylarının \%59,2'si öğretim elemanlarının uygulamada yaşanan sorunlarla ilgilendiğini, \%27'si kısmen ilgilendiğini, $\% 13,7$ 'si ise ilgilenmediklerini ifade etmişlerdir.

Araştırmanın sonucunda diğer paydaşlar öğretim elemanlarıyla ilgili sorunlara çözüm olarak uygulama dersinde deneyimli olanların görevlendirilmesini, değerlendirmede uygulama öğretim elemanları arasında tutarlılık olmasını, uygulama öğretmenleriyle ortak çalışmaların yürütülmesini, ders anlatımlarının daha fazla izlenmesini, belirli aralıklarla toplantılar yapılmasını önermektedirler.

Yapılan görüşmelerde öğretmen adayları okul koordinatörlerinin ders dış1 etkinlikler planlamadıklarını, mesleki mevzuatlarla ilgili bilgilendirme yapmadıklarını, kendileriyle devam durumu dışında iletişis kurmadıklarını ve baskıcı bir yaklaşım sergilediklerini; öğretim elemanları ise okul koordinatörlerinin öğretmen adayının programını planlamalarında sorunlar olduğunu belirtmiş̧lerdir. Yapılan görüşmelerde katılımcıların, okul müdürlerinin ilgili paydaşlarla toplantılar yapmaması, öğretmen adaylarının kendilerini okula ait hissetmelerini sağlayacak ortamı oluşturmaması, kendileriyle iletişim ve işbirliği kurmaması ve uygulama öğretmenlerinin seçiminde yeterliliğe dikkat etmemeleri gibi nedenlerle sorunlar yaşadıkları anlaşılmıştır. Araştırma ile benzer olarak bazı araştırmalarda uygulama okul koordinatörlerinin ders dışı etkinlikler düzenlemedikleri (Katranc1, 2008), okul yöneticilerinin iletişim kurmayarak bilgilendirmeler yapmadıkları (Çelikkaya, 2011; Karaca ve Aral, 2011; Özçelik, 2012) belirlenmiştir. Bektaş ve Ayvaz (2012)'ın çalışmasında da öğretmen adaylarının uygulama okulu koordinatörlerinin ders dışı etkinliklere katılımı sağlamaları ve yönetimle ilgili işlemlerin yapılmasında kendilerine görev vermeleri yönünde beklentileri olduğu belirlenmiştir.

Araştırmada öğretmenlik uygulaması dersinde paydaşların birbirleri ile ilgili sorunlarla karşılaş̧ıkları ve dersin işleniş sürecinde beklentilerin tam olarak karşılanamadığı sonucuna ulaşılmıştır. Öğretmenlik uygulaması dersinin öğretmen adaylarının mesleki yeterlilik edinmelerinde katkısının düşük olduğu Gümüş ve diğerlerinin (2018) çalışmasında da belirtilmiştir. Bu çalışmada öğretmenler staj dönemlerinde aldıkları eğitimin gerçek meslek yaşantılarıyla uyuşmadığını ve etkili olmadığını, öğretmenliği göreve başladıktan sonra öğrendiklerini belirtmişlerdir. Ayrıca Yanık, Bağdat, Gelici ve Taştepe (2016)'nin matematik öğretmenleri ile yaptıkları çalışmada Öğretmenlik Uygulaması dersi sürecinde edinilen deneyimlerin öğretmenlik sırasında yaşanılan sorunlarla baş etmede yeterince katkı sağlamadığ 1 sonucu elde edilmiştir. 
Elde edilen sonuçlar 1şığında öğretmenlik uygulaması sürecinin etkili bir şekilde yürütülebilmesinin önündeki en önemli engelin paydaşların birbirlerine karşı görev ve sorumluluklarını yerine getirmemeleri olduğu söylenebilir. $\mathrm{Bu}$ nedenle paydaşların birbirleri ile ilgili olarak yaşadıkları sorunların tespit edilmesi ve yaşanan sorunlara çözüm üretilmesi noktasında çalışmaların sıklaştırılması oldukça önemlidir. Yapılması gereken çalışmaların başında ilgili tarafların birbirleriyle iletişimlerinin kuvvetlendirilmesi gelmektedir. Bu sayede süreçle ilgili ortak bir anlayışın geliştirilmesi ve yapılan uygulamalar arasında tutarlılığın yakalanması mümkün hale gelebilecektir. Ayrıca paydaşların sorumluluklarını tam olarak neden yerine getiremedikleriyle ilgili kendi görüşleri alınarak ihtiyaçları doğrultusunda iyileştirmeler yapılması gerekmektedir.

\section{KAYNAKÇA}

Alakuş, A. O. (2005). Öğretmen adaylarının okul deneyiminin kazandırdığ 1 mesleki yeterliklere ilişkin algıları. Eğitim ve Bilim, 30(138), 3-9.

Akpınar, M., Çolak, K. ve Yiğit, E. Ö. (2012). Öğretmenlik uygulaması dersi kapsamında sosyal bilgiler öğretmen adaylarının yeterliklerine yönelik uygulama öğretmenlerinin görüşleri. M.Ü. Atatürk Ĕgitim Fakültesi Ĕgitim Bilimleri Dergisi, 36, 41-67.

Akyıldız, S. (2018). Uygulama Öğretim Elemanları ile Uygulama Öğretmenlerinin Görev ve Sorumluluklarını Yerine Getirme Düzeylerinin İncelenmesi. Asian Journal of Instruction, 6(1), 21-39.

Arıkan, Y. D. (2009). Bilişim teknolojileri öğretmen adayları ve öğretmenlik uygulaması dersi. Ege Eğitim Dergisi, 10(1), 1-23.

Aslan, M. ve Sağlam, M. (2018). Öğretmenlik uygulaması dersinin öğretmen adaylarının görüşlerine göre değerlendirilmesi. Hacettepe Üniversitesi Eğitim Fakültesi Dergisi, 33(1), 144-162.

Atmış, S. (2013). Sinıf öğretmeni adaylarının ögretmenlik uygulaması sürecini değerlendirmelerine yönelik görüşlerinin incelenmesi. [Yayınlanmamış yüksek lisans tezi]. Karadeniz Teknik Üniversitesi.

Aydın, F. ve Akgün, Ö. E. (2014). Eğitim Fakültesi BÖTE son sınıf öğrencilerinin okul deneyimi ve öğretmenlik uygulaması derslerinde karşılaştıkları sorunlar. Sakarya Üniversitesi Ĕgitim Fakültesi Dergisi, 28, 1-14. 


\section{Z.Yıldırım Yakar-E.Uzun-B.Tekerek Öğretmenlik Uygulaması Dersi...}

Aytaç, A. (2010). Öğretmenlik uygulaması dersi kapsamında uygulama öğretim elemanlı̆̆ının değerlendirilmesi. [Yayınlanmamış yüksek lisans tezi]. Mehmet Akif Ersoy Üniversitesi.

Aytaçl1, B.(2012). Illköğretim matematik öğretmenliği lisans programında yer alan okul deneyimi ve ögretmenlik uygulaması derslerinin değerlendirilmesi. [Yayınlanmamış yüksek lisans tezi]. Ege Üniversitesi.

Baştürk, S. (2009). Öğretmenlik uygulaması dersinin öğretmen adaylarının görüşlerine göre incelenmesi. İlkögrretim online, 8(2), 439-456.

Bektaş, M. ve Ayvaz, A. (2012). Öğretmen adaylarının öğretmenlik uygulaması dersinden beklentileri. Mersin Üniversitesi Eğitim Fakültesi Dergisi, 8(3), 209-232.

Bural, B. ve Avşaroğlu, S. (2012). Zihin engelliler öğretmenliği öğretim uygulaması dersinde karşılaşılan güçlüklerin öğretmen adayları açısından değerlendirilmesi. Turkish Journal of Education, 1(2), 1- 13.

Büyüköztürk, Ş., Çakmak, K. E., Akgün, Ö. E., Karadeniz, Ş. ve Demirel, F., (2016). Bilimsel araştırma yöntemleri. Pegem Akademi.

Canbolat, C. (2014). Grafik ve görsel sanatlar ögretmen adaylarının ögrretmenlik uygulaması dersine yönelik görüşleri. [Yayınlanmamış yüksek lisans tezi]. Gazi Üniversitesi.

Çelikkaya, T. (2011) Sosyal Bilgiler öğretmen adaylarının öğretmenlik uygulaması dersinden beklentileri ve bu beklentilerin karşılanma düzeyleri. Uluslararası Sosyal Bilimler Eğitimi Dergisi, 1(2), 1-18.

Çepni, O., Aydın, F. ve Şahin V. (2015). Coğrafya öğretmen adaylarının öğretmenlik uygulaması dersi kapsamında karşılaştığı sorunlar ve çözüm önerileri. Türkiye Sosyal Araştırmalar Dergisi, 2(2), 285-304.

Çetin, Ö. F. ve Bulut, H. (2002). Okul deneyimi I, II ve öğretmenlik uygulaması derslerinin uygulama öğretmenleri ve öğretmen adayları tarafindan değerlendirilmesinin incelenmesi. Erzincan Ĕ̆itim Fakültesi Dergisi, 4(2), 69-75.

Danielewicz, J. (2001). Teaching selves: Identity, pedagogy, and teacher education. Albany, State University of New York Press.

Darling-Hammond, L. (2006). Constructing 21st-century teacher education. Journal of teacher education, 57(3), 300-314. 
Değirmençay, Ş. A. ve Kasap, G. (2013). Okul deneyimi ve öğretmenlik uygulaması derslerine ilişkin öğretmen adaylarının görüşleri. Adnan Menderes Üniversitesi Eğitim Fakültesi Ĕgitim Bilimleri Dergisi, 4(2), 4757.

Demir, Ö. ve Çamlı, Ö. (2011). Öğretmenlik uygulaması dersinde uygulama okullarında karşılaşılan sorunların sınıf ve okul öncesi öğretmenliği öğrenci görüşleri çerçevesinde incelenmesi: Nitel bir çalışma. Uludă Üniversitesi Ĕ̈itim Fakültesi Dergisi, 24(1),117-139.

Dursun, Ö. Ö. ve Kuzu, A. (2008). Öğretmenlik uygulaması dersinde yaşanan sorunlara yönelik öğretmen adayı ve öğretim elemanı görüşleri. Selçuk Üniversitesi Ahmet Keleşoğlu Eğitim Fakültesi Dergisi, 25, 159-178.

Ergüneş, Y. (2005). Okul deneyimi dersi uygulamasının öğrenciler tarafından amacına uygun olarak yapılıp yapılmadığının değerlendirilmesi. Balıkesir Üniversitesi Sosyal Bilimler Dergisi, 8(13), 106-128.

Eurydice (2015). The Teaching Profession in Europe: Practices, Perceptions, and Policies. Eurydice Report, Publications Office of the European Union.

Flores, M. A. ve Day, C. (2006). Contexts which shape and reshape new teachers' identities: A multi-perspective study. Teaching and teacher education, 22(2), 219-232.

Gökçe, E. ve Demirhan, C. (2005). Öğretmen eğitiminde yenilikçi bir yaklaşım mı yoksa geleneksel bir anlayış mı? Ankara Üniversitesi Eğitim Bilimleri Fakültesi Dergisi, 38(2), 187-195.

Görgen, İ., Çokçalışkan, H. ve Korkut, Ü. (2012). Öğretmenlik uygulaması dersinin öğretmen adayları, uygulama öğretmenleri ve uygulama öğretim üyeleri açısından işlevselliği. Muğla Üniversitesi Sosyal Bilimler Enstitüsü Dergisi, 28, 56-72.

Gümüş, N., Özbaş, B. Ç., Gülersoy, A. E., Duman, D., Türker, H., Avcı, G. ve Dikicigil, Ö. (2018). Sosyal bilgiler öğretmenlerinin" öğretmenlik uygulaması" dersine ilişkin görüş ve önerileri. Electronic Turkish Studies, 13(11), 593-613.

Gündoğdu, K., Altın, M., Üstündağ, N. ve Altay, B. (2018). Öğretmen adayları ögretmenlik uygulamasında yeterli mi?(Bir olgubilim çalışması). Adnan Menderes Üniversitesi Sosyal Bilimler Enstitüsü Dergisi, 5(1), 150-166.

Güzel, H., Berber, N. C. ve Oral, İ. (2010). Eğitim fakültesi uygulama okulları işbirliği programında görevli öğretmenlerin ve öğretim elemanlarının 


\section{Z.Yıldırım Yakar-E.Uzun-B.Tekerek Öğretmenlik Uygulaması Dersi...}

öğretmenlik uygulamasına yönelik görüşleri. Kastamonu Eğitim Dergisi, 18(1), 19-36.

Hurioğlu, L. (2016). Öğretmenlik uygulaması dersinde dönüt-düzeltmenin ögretmen adaylarının öğretimi planlama ve uygulama becerileri ile özyeterlik düzeylerine etkisi. [Yayınlanmamış Doktora Tezi], Çukurova Üniversitesi.

Kale, M. (2011). Öğretmen adaylarının öğretmenlik uygulaması dersinde karş1laştıkları sorunlar. Türk Eğitim Bilimleri Dergisi, 9(2), 255-280.

Karaca, N. H. ve Aral, N. (2011). Okul öncesi ögretmen adaylarının öğretmenlik uygulamalarında karşılaştıkları sorunlar, 2nd International Conference on New Trends in Education and Their Implications 27-29 April, 2011 Antalya-Turkey.

Karadüz A., Eser Y., Şahin C. ve İlbay A.(2009). Eğitim fakültesi son sınıf öğrencilerinin görüşlerine göre Öğretmenlik uygulaması dersinin etkililik düzeyi. Mustafa Kemal Üniversitesi Sosyal Bilimler Enstitüsü Dergisi. 6 (11), 442-455.

Katranc1, M. (2008). Öğretmenlik uygulamasinda uygulama okulu koordinatörleri ve uygulama ögretmenlerinin görev ve sorumluluklarını yerine getirme düzeyleri (Kırıkkale ili örneği). [Yayınlanmamış Yüksek Lisans Tezi]. Kırıkkale Üniversitesi.

Kökçü, Y. (2015). Türkçe öğretmen adaylarının okul deneyimi ve öğretmenlik uygulaması dersleri kapsamında uygulama öğretmenleri hakkındaki görüşleri. International Periodical for the Languages, Literature and History of Turkish or Turkic, 10(15), 585-600.

MEB (2017). Öğretmenlik Mesleği Genel Yeterlikleri. Öğretmen Yetiştirme ve Eğitimi Genel Müdürlüğü.

Oğuz, A. (2004). Okul deneyimi I dersinin öğretmen adayları üzerindeki etkileri. Dumlupınar Üniversitesi Sosyal Bilimler Dergisi, 11, 141- 163.

Özçelik, N. (2012). Yabancı dil öğretmen adaylarının okul deneyimi ve öğretmenlik uygulaması dersine ilişkin görüşleri. GEFAD, 32(2), 515-536.

Paker, T. (2008). Öğretmenlik uygulamasında öğretmen adaylarının uygulama öğretmeni ve uygulama öğretim elemanının yönlendirmesiyle ilgili karşılaştıkları sorunlar. Pamukkale Üniversitesi Ĕgitim Fakültesi Dergisi, 23, 132-139. 
Petek, B. (2014). Öğretmenlik uygulaması dersinin sosyal bilgiler öğretmen adaylarının mesleki yeterlilikleri üzerindeki etkisi (Erzurum Örneği). [Yayınlanmamış yüksek lisans tezi]. Atatürk Üniversitesi.

Rakıcıoğlu Söylemez, A. Ş. (2012). İngilizce öğretmen adaylarının öğretmenlik uygulaması dersi boyunca ögretmen öz yeterlik inançları ve danışmanlık uygulamalarına yönelik görüşleri üzerine keşifsel bir durum çalışması. [Yayınlanmamış doktora tezi]. Orta Doğu Teknik Üniversitesi.

Seçer, Z., Çeliköz, N. ve Kayılı, G. (2010). Okul öncesi öğretmenliği okul uygulamalarında yaşanan sorunlar ve çözüm önerileri. Yüzüncü Y Yll Üniversitesi, Eğitim Fakültesi Dergisi, 7(1), 128-152.

Smith, K. ve Lev Ari, L. (2005). The place of the practicum in pre-service teacher education: The voice of the students. Asia-Pacific Journal of Teacher Education, 33(3), 289-302.

Süral, S. (2017). Sınıf öğretmenliği öğretmen adaylarının öğretmenlik uygulaması dersindeki uygulama öğretmenleri hakkındaki düşüncelerinin incelenmesi. Bilecik Şeyh Edebali Üniversitesi Sosyal Bilimler Enstitüsü Dergisi, 2(1), 277-299.

Topkaya, E. Z. ve Yalın, M. (2006). Uygulama Öğretmenliğine ilişkin Tutum Ölçeği Geliştirilmesi. Eğitimde Kuram ve Uygulama, 1(1-2), 14-24.

Turgut, M., Y1lmaz, S. ve Firuzan, A.R. (2008). Okul deneyimi uygulama sürecinin değerlendirilmesi üzerine bir araştırma. Üniversite ve toplum. [http://www.universite toplum.org/text.php3?id=361 adresinden 10 Nisan 2010 Tarihinde indirilmiştir.]

Yalın Uçar, M. (2012). Öğretmenlik uygulamasına ilişkin durum çalışması. Kuram ve Uygulamada Eğitim Bilimleri, 12(4), 2637- 2660.

Yalın Uçar, M. (2008). Önerilen “uygulama öğretmeni eğitim programı”nın uygulama ögretmenliğine ilişsin yeterliliğe ve tutuma olan etkisi. [Yayımlanmamış doktora tezi], Hacettepe Üniversitesi.

Yanık, H. B., Bağdat, O., Gelici, Ö. ve Taştepe, M. (2016). Göreve yeni başlayan ortaokul matematik öğretmenlerinin karşılaştıkları zorluklar. Mustafa Kemal Üniversitesi Sosyal Bilimler Enstitüsü Dergisi, 13(36), 130-152.

Yeşilyurt, E. ve Semerci, Ç. (2011). Uygulama öğretmenlerinin öğretmenlik uygulamas1 sürecinde karşılaştıkları sorunlar ve çözüm önerileri. Akademik Bakış Dergisi, 27, 1-23. 


\section{Z.Yıldırım Yakar-E.Uzun-B.Tekerek Öğretmenlik Uygulaması Dersi...}

Yeşilyurt, E. ve Semerci, Ç. (2012). Öğretmenlik uygulaması öğretim programının standart temelli değerlendirme modeli 1şı̆̆ında değerlendirilmesi. International Online Journal of Educational Sciences, 5(1), 188-210.

Yıldırım, A.(2018). Prof. Dr. Ali Yıldırım ile Türkiye'de Öğretmen Yetiştirme Süreci Üzerine. Söyleşiyi yapan: Tedmem . https://tedmem.org/soylesi/prof-dr-ali-yildirim-ile-turkiyede-ogretmenyetistirme-sureci-uzerine

Yıldırım, A. ve Şimşek, H. (2016). Sosyal bilimlerde nitel araştırma yöntemleri (10. Baskı). Seçkin Yayıncılık.

Yıldız, M. A. (2012). Türkçe ögretmenliği lisans programında yer alan ögretmenlik uygulaması dersinin değerlendirilmesi. [Yayınlanmamış yüksek lisans tezi]. Kilis 7 Aralık Üniversitesi.

Yılmaz, M. (2011). Sınıf öğretmeni adaylarının öğretmenlik uygulaması dersini yürüten öğretim elemanlarına ilişkin görüşleri. Gaziantep Üniversitesi Sosyal Bilimler Dergisi, 10(4), 1377-1387.

Yılmaz, A. ve Namlı, S. (2017). Öğretmenlik uygulaması dersine katılan uygulama öğretmeni ve öğretmen adaylarının mesleki yeterliklerine ilişkin görüşleri. Uluslararası Insan Bilimleri Dergisi, 14(3), 3061-3077.

YÖK (1998). Fakülte-okul işbirliği kılavuzu. Yüksek Öğretim Kurulu Yayınları.

YÖK (2007). Öğretmen yetiştirme ve eğitim fakülteleri (1982-2007). Yükseköğretim Kurulu Yayını

YÖK (2018). Öğretmen yetiştirme lisans programlarl, programların güncelleme gerekçeleri, getirdiği yenilikler ve uygulama esasları. [17.08.2018tarihindehttp://www.yok.gov.tr/web/guest/icerik//journal_con tent/56 INSTANCE rEHF8BIsf adresinden alınd1. 